\title{
Infantile Overnutrition among Artificially Fed Infants in the Sheffield Region
}

\author{
L. S. TAITZ
}

British Medical fournal, 1971, 1, 315-316

\section{Summary}

Artificially-fed 6-week-old infants in the Sheffield region are heavier than would be predicted from their birth weights and show a greatly increased incidence of excessive weight gain. These findings are associated with caloric intakes that exceed the classic 50 calories/lb/day (110 calories/ $\mathrm{kg} /$ day) with a universal tendency to early feeding with cereals and mixed infant foods.

The possible harmful implications of the trend to infantile overnutrition are discussed.

\section{Introduction}

Overnutrition of very young infants has only recently become a subject for serious debate (Cochrane, 1965). The old adage that "one cannot overfeed a young baby" has for long been a cornerstone in the dogma connected with infant feeding. In a recent review of nutrition in children infantile overnutrition is not discussed and the babies of the world are exhorted to "eat, drink, and be merry" (Wharton, 1970). Yet there remains the uncomfortable fact that obesity in older children and adults is now a serious problem in affluent lands (Shank, 1965), and it may be that excessive calorie intake in early life is a causative factor. The suggestion that the number of adipose cells present through life is largely determined in early life is an added cause for concern (Beaton, 1967), particularly as it has been shown in Sheffield that weight gain in the neonatal period (Eid, 1970) can be correlated with the weight in later childhood.

Excessive weight gain in the very young infant is thus a subject of some importance, and this communication records the high incidence of rapid weight gain in artificiallyfed infants in the Sheffield region.

\section{Patients and Methods}

The infants included were a consecutive unselected series of 261 normal full-term infants who had been born in the hospital and who returned to the professorial well-baby clinic at the Jessop Hospital, Sheffield. It is the policy of the unit to try to see at 6 weeks of age all infants born in the hospital; the attendance rate is about $80 \%$.

The birth weight and the weight at 6 weeks were recorded and plotted on the centile charts devised by Tanner (1958) and the resulting distribution was analysed by appropriate statistical methods. Weight gain velocities were calculated by the method of Tanner et al. (1966).

\section{Results}

Of 120 males 6 were predominantly breast-fed ( $5 \%$ ) whereas of 141 females $15(10.6 \%)$ were breast-fed. This apparent difference in distribution between males and females is not statistically significant $\left(\chi^{2}=2.79,0.05<\mathrm{P}<0.10\right)$.

The centile distribution of weights at birth and at 6 weeks

University of Sheffield, Sheffield 10

L. S. TAITZ, M.D., B.SC., Lecturer in Child Health is represented in Table I. At birth seven males were above the 90th centile, 48 were between the 50th to 90th centiles, and 59 were between the 10th to 50th centiles. At 6 weeks the values were 46,52 , and 16 infants respectively. The birth weights of the females had the following distribution: above the 90th centile, 9; 50th to 90th centiles, 7; and 10th to 50th centiles, 47. The corresponding distribution of weights at 6 weeks was 47,63 , and 16 babies. The apparent change in centile distribution for both males and females was highly significant (males $\chi^{2}=53.53, P<0.001 ;$ females $\chi^{2}=41.41$, $\mathrm{P}<0.001$ ).

The weight gain velocities between birth and 6 weeks in artificially fed babies are given in Table II. Of 114 males 85 $(74.6 \%)$ showed gains which exceeded the 90th centile, whereas $58(46.0 \%)$ of the females showed a similar weight gain velocity. This apparent difference in incidence of increased weight gain velocities between males and females is statistically significant $\left(\chi^{2}=20.23, P<0.001\right)$. The weight gain velocities of artificially-fed and breast-fed infants are compared in Table III. Of 21 breast-fed infants 4 (19\%) exceeded the 90th centile, whereas $143(59.6 \%)$ of 240 artificially-fed infants did so. This difference is highly significant $\left(\chi^{2}=11.30\right.$, $\mathbf{P}<0.001$ ).

\section{Feeding Practices Current in Sheffield Region}

The calorie intake of 40 infants at the age of 6 weeks was based on a careful dietary history and the assumption that each ounce $(28 \mathrm{ml})$ of milk formula contained 20 calories. To

TABLE I-Comparison of Birth Weight and 6-week Centile Distribution

\begin{tabular}{|c|c|c|c|c|c|}
\hline & & $>90$ & $50-90$ & $10-50$ & Total \\
\hline $\begin{array}{l}\text { Males- } \\
\text { artificial feeding }\end{array}$ & $\begin{array}{l}\text { Birth } \\
6 \text { weeks* }\end{array}$ & $\begin{array}{r}7(6 \cdot 1 \%) \\
46(40 \cdot 4 \%)\end{array}$ & $\begin{array}{l}48(42.9 \%) \\
52(45.6 \%)\end{array}$ & $\begin{array}{l}59(51.8 \%) \\
16(14 \%)\end{array}$ & $\begin{array}{l}114 \\
114\end{array}$ \\
\hline $\begin{array}{l}\text { Females- } \\
\text { artificial feeding }\end{array}$ & $\begin{array}{l}\text { Birth } \\
6 \text { weekst }\end{array}$ & $\begin{array}{r}9(7 \cdot 1 \%) \\
47(37 \cdot 3 \%)\end{array}$ & $\begin{array}{l}70(55 \cdot 6 \%) \\
63(50 \%)\end{array}$ & $\begin{array}{l}47(37 \cdot 3 \%) \\
16(12 \cdot 7 \%)\end{array}$ & $\begin{array}{l}126 \\
126\end{array}$ \\
\hline Total & $\begin{array}{l}\text { Birth } \\
6 \text { weeks }\end{array}$ & $\begin{array}{l}16(6.7 \%) \\
93(38.8 \%)\end{array}$ & $\begin{array}{l}118(49 \cdot 1 \%) \\
115(47.9 \%)\end{array}$ & $\begin{array}{r}106(44 \cdot 2 \%) \\
32(13 \cdot 3 \%)\end{array}$ & $\begin{array}{l}240 \\
240\end{array}$ \\
\hline Breast-fed & $\begin{array}{l}\text { Birth } \\
6 \text { weeks }\end{array}$ & $\begin{array}{l}1(4.8 \%) \\
4(19 \cdot 1 \%)\end{array}$ & $\begin{array}{l}12(57 \cdot 1 \%) \\
10(47 \cdot 6 \%)\end{array}$ & $\begin{array}{l}8(38 \cdot 1 \%) \\
7(33 \cdot 3 \%)\end{array}$ & $\begin{array}{l}21 \\
21\end{array}$ \\
\hline
\end{tabular}

* Males: $x^{2}=53.51$. Significant, $P<0.001$.

†Females: $\chi^{2}=41.41$. Significant. $P<0.001$

TABLE II-Weight Gain Velocities in Artificially-fed Babies

\begin{tabular}{cccc|c|c|c|c} 
& & & & $\begin{array}{c}\text { Above } \\
90 \text { th } \\
\text { Percentile }\end{array}$ & $\begin{array}{c}\text { Below } \\
\text { 90th } \\
\text { Percentile }\end{array}$ & $\begin{array}{c}\text { Percentage } \\
\text { above } \\
90 \text { th }^{*}\end{array}$ \\
\hline Males $\ldots$ & $\ldots$ & $\ldots$ & $\ldots$ & 114 & 85 & 29 & $74 \cdot 6$ \\
\hline Females & $\ldots$ & $\ldots$ & $\ldots$ & 126 & 58 & 68 & 46.0 \\
\hline Total &. & $\ldots$ & $\ldots$ & 240 & 143 & 97 & $59 \cdot 6$ \\
\hline
\end{tabular}

${ }^{*} \chi^{2}=20 \cdot 23$. Significant, $P<0.001$

this was added the estimated additional calorie intake, based on an account of supplementary feeds given to the babies and their caloric content as supplied by the manufacturers. Nonmilk supplements were given to all the babies without exception, and in most infants their introduction into the diet had begun during the first week of life. The types of food used covered the entire range of commercially available products (Table IV).

The distribution of estimated calorie intake was less than $50 \mathrm{cal} / \mathrm{lb}(110 \mathrm{cal} / \mathrm{kg})$ per day in 1 infant, $50-59 \mathrm{cal} / \mathrm{lb}$ 
TABLE III-Weight Gain Velocities at 6 Weeks

\begin{tabular}{|c|c|c|c|c|c|c|c|}
\hline & & & & & Total & $\begin{array}{c}\text { Gain above } \\
\text { 90th Centile } \\
\text { No. }\end{array}$ & Percentage* \\
\hline $\begin{array}{l}\text { Breast-fed } \\
\text { Artificial feeds " }\end{array}$ & $\because$ & $\because$ & $\because$ & $\because$ & $\begin{array}{r}21 \\
240\end{array}$ & $\begin{array}{r}4 \\
143\end{array}$ & $\begin{array}{l}19 \cdot 0 \\
59 \cdot 6\end{array}$ \\
\hline
\end{tabular}

${ }^{*} \chi^{2}=11 \cdot 30$. Significant, $P<0.001$.

TABLE IV-Representative Examples of Overfeeding with Excessive Weight Gain at 6 Weeks of age

\begin{tabular}{|c|c|c|c|c|c|}
\hline Sex & $\underset{\text { Weight }}{\text { Birth }}$ & $\begin{array}{l}\text { Weight at } \\
6 \text { Weeks }\end{array}$ & $\begin{array}{l}\text { Gain in } \\
\text { Weight }\end{array}$ & Diet & Calories/Day \\
\hline M. & $2 \cdot 8 \mathrm{~kg}$ & $5 \cdot 3 \mathrm{~kg}$ & $2.5 \mathrm{~kg}$ & $\begin{array}{l}\text { 1. Full cream milk } 30 \mathrm{oz} \\
(850 \mathrm{~g}) \text { daily } \\
\text { 2. Cereal } 1 \text { tablespoonful } \\
\text { per feed } \\
\text { 3. } \\
\text { 4. t tin of baby food } \\
\text { 1 whole rusk }\end{array}$ & 800 \\
\hline M. & $2.6 \mathrm{~kg}$ & $5.5 \mathrm{~kg}$ & $2.9 \mathrm{~kg}$ & $\begin{array}{l}\text { 1. Full cream milk } 30 \mathrm{oz} \\
\text { ( } 850 \mathrm{~g} \text { ) daily } \\
\text { 2. One rusk in each feed }\end{array}$ & 800 \\
\hline F. & $3 \cdot 1 \mathrm{~kg}$ & $5 \cdot 2 \mathrm{~kg}$ & $2.0 \mathrm{~kg}$ & $\begin{array}{l}\text { 1. Full cream milk } 30 \mathrm{oz} \\
(850 \mathrm{~g}) \text { daily } \\
\text { 2. I rusk } \\
\text { 3. Two heaped } \\
\text { tablespoonfuls baby food } \\
\text { 4. Two tablespoonfuls } \\
\text { cereal daily }\end{array}$ & 750 \\
\hline F. & $3.0 \mathrm{~kg}$ & $5.0 \mathrm{~kg}$ & $2.0 \mathrm{~kg}$ & $\begin{array}{l}\text { 1. S.M.A. } 20 \mathrm{oz}(570 \mathrm{~g}) \\
\text { daily } \\
2 \text { tablespoonfuls cereal } \\
\text { daily } \\
\text { 3. One rusk daily } \\
\text { 4. One tin baby food daily }\end{array}$ & 700 \\
\hline M. & $4 \mathrm{~kg}$ & $6 \cdot 1 \mathrm{~kg}$ & $2 \cdot 1 \mathrm{~kg}$ & $\begin{array}{l}\text { 1. Full cream milk } 32 \mathrm{oz} \\
(900 \mathrm{~g}) \\
\text { 2. Rusks } 1 \text { daily } \\
\text { 3. Cereal } 1 \text { tablespoonful } \\
\text { with each feed }\end{array}$ & 800 \\
\hline
\end{tabular}

(110-130 cal $/ \mathrm{kg})$ per day in 24 infants, $60-70 \mathrm{cal} / \mathrm{lb}(135-160$ $\mathrm{cal} / \mathrm{kg})$ per day in 11 infants, and $>70 \mathrm{cal} / \mathrm{lb}(160 \mathrm{cal} / \mathrm{kg})$ per day in 4 infants. The mean calorie intake was $60 \mathrm{cal} / \mathrm{lb}$ $(135 \mathrm{cal} / \mathrm{kg})$ per day.

\section{Discussion}

It is apparent that the weights of artificially-fed babies in the South Yorkshire area are substantially greater at 6 weeks of age than expected on the basis of the Tanner centile charts. Furthermore, 143 infants $(59.6 \%)$ out of 240 showed a weight gain velocity above the 90th centile. Babies delivered at the Jessop Hospital are from "at risk" pregnancies and it is possible that this had led to overprotective attitudes in the parents and therefore to overfeeding. This seems unlikely, and even if true would still constitute a significant proportion of the total births in the Sheffield region. It seems reasonable to postulate that these findings represent part of a general trend to excessive weight gain in the neonatal period.

Several factors account for the tendency to overfeed young infants. It is often encouraged by grandmothers, midwives, nurses, health visitors, welfare clinics, and even physicians, and by the popular notion of the "bonny" baby with bloated cheeks and limbs, protuberant belly, and the various signs of the "Michelin Tyre Man" syndrome. The apparently low resistance of present-day mothers to the crying infant and the tendency to provide instant gratification in a caloric form may also play its part.

The institution of full mixed feeding usually results in a return of the weight to normal in later infancy and no damage is done in most infants. The findings of Eid (1970), however, indicate that overall incidence of obesity is related to the rate of early weight gain. Furthermore, there is evidence that the high solute load involved in the increased intake of food might predispose infants who become ill to hypernatraemic dehydration (Taitz, unpublished data). The finding should thus at least be considered as a nutritional and public health problem which requires careful evaluation.

The observation that excess weight gain is more striking in males than in females requires comment. It was also found in the study by Eid, but there appears to be no ready explanation for it. More data are clearly required to elucidate this problem.

The recent vogue for the early introduction of non-milk feeds has undoubtedly been given impetus by the not unnatural desire of manufacturers to sell their products. There is no doubt at all that increasing the calorie intake of the diet from a very early age will increase the rate of weight gain, and so long as this is the sole criterion of good nutrition it is not surprising that an intensive campaign of advertising should result in the excessive use of high-calorie additives and supplementary feeds. Examination of dietary advice supplied by the producers shows how suggestions are made to mothers that can lead only to the aggravation of the tendency to overfeed babies. One brochure suggests that a particular advantage of a certain range of foods is that "you can mix them as thick or as thin as your baby likes" without any reference at all to the calorie implications of such variations in consistency. It also states that "some babies do best if they are given solids almost from birth"-a highly questionable conclusion, particularly when the criterion for "doing best" can only be that of greater velocity of weight gain.

Another alarming factor is the advice given for the management of the baby who is "restless, fractious, or always hungry." The answer it seems is to increase the calorie intake by adding one of the starchy, sugary preparations which seem to account for the bulk of the available foods. The habit of crumbling various brands of baby rusks in the milk formula seems particularly unnecessary.

The widespread habit that seems to have crept into infant feeding in recent years of regarding the composition of reconstituted milk formulae in a cavalier fashion requires further comment. The concentration of the feeds, and therefore of calories, amino-acids, and sodium, of ten exceeds that of cows' milk (Taitz, unpublished data). The resulting solute load and demands on the kidney to excrete the excess of electrolyte and urea may lead to greatly increased water requirements. The "restless, fractious always hungry baby" may well in truth be the overstuffed infant with a great thirst.

Clearly we have lost sight of a number of basic principles in infant feeding derived from the composition of human milk and the rate of weight gain of the normal breast-fed infant. Babies require a certain minimum water intake which can be closely related to the intake of calories and solute. Water and food requirements are not synonymous, and a clear distinction must be made between the volume of fluid needed and its composition. If calories are added in the form of solid foods a corresponding reduction in the calorie content but not the volume of milk formula is indicated. The classic "two and a half ounces per pound per day containing 20 calories per ounce" remains a rule of thumb unsurpassed in its simplicity and unchallenged by the years of investigation and experience. There is no evidence that anything can be gained by exceeding this intake during the first few months of life apart from the spurious achievement of greater weight gain.

I wish to thank Professor R. S. Illingworth and Dr. V. Dubowitz for their encouragement and advice, and Professor J. Knowelden and Miss J. Rhodes for their advice and help with the statistical presentation of the data.

\section{References}

Beaton, J. R. (1967). Canadian Fournal of Public Health, 58, 479.

Cochrane, W. A. (1965). Canadian Medical Association fournal, 93, 893.

Eid, E. E. (1970). British Medical fournal, 2, 74

Eid, E. E. (19) an Epidemiologic Approach, ed. H. R. Leavell, and E. G. Clark, 3rd edn., p. 171. New York, McGraw Hill.

Tanner, I. M. (1958). In Modern Trends in Paediatrics-2, ed. A. Holzel and I. P. M. Tizard. London, Butterworth

Tanner, J. M., Whitehouse, R. H., and Takaishi, M. (1966). Archives of Disease in Childhood, 41, 613.

Wharton, B. A. (1970). In Modern Trends in Paediatrics-3, ed. J. Apley, p. 202. London, Butterworth 